\title{
JUBILACIÓN (UNA POÉTICA)
}

\section{Luis ARTIGUE}

\author{
A José Enrique Martínez
}

Un poema que nos deje solos ante un vino rojo espeso que demande queso y pan.

Un alegato de la fluidez musicalmente irregular o audaz — siempre nos gustó que la métrica fuera una imprecisión complementaria con la que también hablar de la impredecibilidad que caracteriza todo-.

\section{Sí, un poema}

tan sórdidamente confesional

como una mazmorra de alterne, o una herida larga y lenta como un blues, o ciertas gotas de luna diluida en la lucerna de la casa madre.

Un intercambio simbiótico.

Una noche tan eficientemente oscura como para que nos aflija el paisaje de nuestra alma y en la que ambos seamos ordenados monjes de la palabra y la escucha, a pesar de seguir siendo nosotros: tú con tu rostro emperillado de Thelonius Monk blanco 
y tus gafas que leen solas,

pero siempre tan sinfónico

o poco activo en el reino

de la disidencia y la discordia;

yo tan ebrio de jazz

como quien ya ha pagado

el republicano precio

de aquellos que se exceden en pasión,

pero no deja de hacer de vez en vez

ese alegato contra la vida breve

que es el hablar sin pausas.

Un poema

transitivo.

Un concierto de música versal

tan fervorosamente heterodoxa

como un santo que liga para ser más perfecto,

el cual nos reúna y perfume con los sonidos del otro

al tiempo que nos confiese que no se trata del dogma

sino del hombre...

Ahora que eres lo suficientemente viejo

para saber que cuanto más viejo te haces

más profundo es el amor que necesitas

te convoco en verdad a un poema jazzístico, aventurero, raudo, loco

que nos haga mirarnos de modo tan inspirado, extraacadémico,

que haga falta tachar las preceptivas

para reconocer

que tenemos un algo de ventrílocuos;

que a veces hay cosas que quieren hablar

$y$, si permanecemos en extenuante silencio,

podremos oírlas,

y si, además, somos

bendecidos vendimiadores de la luz

podremos escribirlas...

Eso, un poema que nos deje a solas

con una botella de vino

que no haga otra cosa que acabarse.

Un concierto para orquesta

y sirena de coche patrulla. 
Tropelías. Revista de Teoría de la Literatura y Literatura Comparada, número extraordinario 1 (2017) 295

Una despedida encharcadamente emotiva escrita así, con el corazón en la mano

y cierto miedo a temblar por si se me cae,

el cual acabe antes de apagar la luz del asfixiante oficialismo

diciéndote

gracias. 